\title{
Relationship Between Parents' Parenting And Independence Level Of Activity Daily Living (ADL) In Soft Mental Retardation Children
}

\author{
Desak Made Ari Dwi Jayanti ${ }^{1}$, R. Tri Rahyuning Lestari ${ }^{1}$, Ni Putu Riskayanti ${ }^{1}$ \\ ${ }^{1}$ STIKes Wira Medika Bali \\ Jalan Kecak No. 9A, Tonja, Kec. Denpasar Utara, Kota Denpasar, Bali \\ Email: djdesak@gmail.com
}

\begin{abstract}
Abstrak
Anak retardasi mental adalah anak yang memiliki keadaan intelegensia yang kurang sejak masa perkembangannya. Pola asuh sangat berpengaruh terhadap kemandirian anak retardasi mental ringan karena pola asuh yang baik dari orang tua akan membantu anak retardasi mental ringan untuk memenuhi kebutuhan activity daily living (ADL) secara mandiri. Tujuan dari penelitian ini adalah untuk mengetahui hubungan pola asuh orang tua dengan tingkat kemandirian activity daily living $(A D L)$ pada anak retardasi mental ringan di SLB Negeri 1 Tabanan. Penelitian ini menggunakan desain deskritif korelasional dengan pendekatan cross sectional. Jumlah sampel yang digunakan sebanyak 51 responden, dengan menggunakan teknik total sampling dengan uji menggunakan Chi-Square. Hasil yang diperoleh orang tua menggunakan pola asuh demokratis sebanyak 40 responden $(78,4 \%)$, sedangkan untuk tingkat kemandirian activity daily living (ADL) pada anak retardasi mental ringan dikategorikan mandiri sebanyak 27 orang (52,9\%), didapatkan angka $p$ value sebesar $0,002(p<0,05)$ maka ada hubungan pola asuh orang tua dengan tingkat kemandirian activity daily living $(A D L)$ pada anak retardasi mental ringan di SLB Negeri 1 Tabanan. Disarankan agar orang tua menerapkan pola asuh yang tepat kepada anaknya dan memberikan motivasi sertadorongan kepada anaknya untuk menggali potensi kemampuan anak khususnya dalam hal kemandirian activity daily living (ADL).
\end{abstract}

Kata kunci : pola asuh, activity daily living, anak retardasi mental ringan

\begin{abstract}
Mental retardation children are children who have a lack of intelligence from the time of their development. Parenting is very influential on the independence of children with mild mental retardation because good parenting from parents will help mild mentally retarded children to fulfill their activity daily living needs $(A D L)$ independently. The purpose of this study was to determine the relationship of parenting parents with an independent level of activity daily living $(A D L)$ in children with mild mental retardation in Tabanan 1 State SLB. This study uses a descriptive correlational design with a cross-sectional approach. The number of samples used was 51 respondents, using a total sampling technique with a test using Chi-Square. The result obtained by parents using democratic parenting as many as 40 respondents (78.4\%), while for the level of independence of daily living activities $(A D L)$ in mild mental retarded children categorized as independent as many as 27 people $(52.9 \%)$, obtained a number $p$-value is $0,002(p<0,05)$ so there is a correlation between parenting style with the level of independence of daily living activity $(A D L)$ in mild mental retarded children in SLB 1 Tabanan. It is recommended that parents apply proper parenting to their children and provide motivation to their children to explore the potential abilities of children, especially in terms of independence of activity daily living (ADL).
\end{abstract}

Keywords: parenting, activity daily living, mild mental retardation children 
Article info:

Article submitted on February 11, 2020

Articles revised on April 03, 2020

Articles received on May 12, 2020

DOI: http://dx.doi.org/10.21927/jnki.2020.8(2).87-94

\section{INTRODUCTION}

Mental retardation is a condition with a lack of intelligence since the development (whether from birth or childhood). In general, there is a lack of overall mental development in children who have mental retardation resulting in retarded intelligence function (Toifur, 2012) (1). Problems that occur in children with mental retardation are weakness or disability in children as well as less ability to fulfill the independence of daily living activities. Independence of daily living activities (ADL) in mentally retarded children experience barriers due to decreased adaptive function experienced, so they can not do daily activities such as bathing, brushing teeth, dressing, and eating independently (Ramawati, et al., 2012) (2).

According to WHO (World Health Organization), the number of children with mental retardation in the world was estimated at $1-8 \%$, seen from the total population in the world (WHO, 2017) (3). The principal data of special schools throughout Indonesia (BPS, 2014) based on the number of population in Indonesia who suffer from mental retardation was 62,011 people, with a ratio of $60 \%$ suffered by boys and $40 \%$ suffered by girls. This number showed the number of children suffering from mild mental retardation was $3.5 \%$, moderate mental retardation children were $2.6 \%$, children with severe mental retardation was $2.8 \%$, and children with very severe mental retardation was 2.5\% (Pratiwi, 2017) (4). Data from the Social Service of Bali Province showed that the number of people with mental retardation in Bali Province had increased wherein 2013 there were 1,326 sufferers, in 2015 there were 2,275 sufferers and in 2017 there were 2,754 sufferers. This data showed an increase every year in 9 districts in Bali (5).

Children with mild mental retardation had less in intellectual intelligence which was below the average, experiencing a disruption in motoric function, and interference with independence in daily activities so that they were depending on others. That independence is important not only for normal children but also for children with mental retardation. A person's independence is not only influenced by the inherent nature of the individual but also influenced by various stimulations that come from the environment, one of them is education from the family, namely parenting patterns for the child (Arfandi, 2013) (6). Parenting is one of the important factors in developing or inhibiting the growth of children's creativity. Parenting is considered a determinant factor that influences the development of independence in Activity Daily Living such as personal hygiene, elimination, eating, drinking, and dressing (Wong, 2009) (7). Parenting is the attitude of parents in interacting with their children, including how parents provide rules, rewards, and punishments, how parents pay attention to their children (Tarmudji, 2012) (8).

The result of this study was in accordance to research by Sari (2014) with the title "The Relationship between Parenting and Social Development of Children with Mental Retardation in SLB C Negeri Denpasar" with 39 respondents (61.9\%) applying democratic parenting. It can be concluded that more parents were implementing democratic parenting than other parenting because democratic parenting gave children 
freedom and responsibility for what they do and mutual respect between children and parents (9).

Children with mild mental retardation were still able to be trained and educated so that the future impact on the assignment of self-care skills can be independently developed even if the results are not minimal (Ramawati, et al., 2012) (2). Reducing dependency and limitations in activities for children with mental retardation could be trained through special education, exercises, providing knowledge and skills about daily life activities (Apriliyanti, 2016) (10).

The result of the preliminary study conducted by researchers on January 11, 2018, in SLB 1 Tabanan which is located at Jl. Pulau Batam No.4, Tabanan, there were 51 children with mild mental retardation who attend SLB Negeri 1 Tabanan. Based on the interview results of 10 parents of students with mental retardation disorders, in case of children ability in self-care, showed that 8 children assisted in bathing hygiene, 6 children rarely brush their teeth, 5 children were less neat in dressing, 6 children were still fed when having a meal, 5 children do not wash their hands before eating. The results of interviews towards the parents about how the treatment is carried out by parents to their children to be able to perform self-care activities independently, 6 parents tend to obey and agree to all wishes of their children, because for parents if their children do not cry and do not interfere with their activities is quite helpful. 2 parents tend to be over-protective and insisted to help all the activities of their child even though the child could do it himself. There were 2 parents trying to train and foster children regularly and provided freedom and responsibility to their children to take care of themselves (11).

Based on the description above, researchers felt the need to research parents' parenting towards the independence level of Activity Daily Living (ADL) in children with mild mental retardation.

\section{MATERIALS AND METHODS}

This research was quantitative with the research design used was a cross-sectional correlational descriptive study which was conducted in SLB Negeri 1 Tabanan in MarchApril 2019. The population was all parents and children with mild mental retardation in SLB Negeri 1 Tabanan as many as 51 parents. The total sampling technique of measuring data collection on parenting variables used a questionnaire according to research by Kendari (2016) and validity testing of 30 respondents in SLB Negeri 1 Denpasar with the results of Alpha Cronbach's reliability was 0.944 which means reliable while the measuring tool to assess the independent variable of Activity Daily Living $(A D L)$ on mental retardation children was taken in Dewi's research (2017) and validity tests were conducted for 30 respondents in SLB Negeri 1 Denpasar, the results of instrument reliability obtained Alpha Cronbach's value of 0.971 which means reliable. Bivariate analysis using the ChiSquare test.

\section{RESULTS AND DISCUSSION \\ Characteristics of research subjects}

According to Table 1, the characteristics of mild mental retardation children based on the age of the children show an average age of 10.61 years with the youngest was 7 years and the age of the oldest child was 18 years, and the characteristics of parents based on the age of parents show an average age of 40,33 years old with the youngest parents was 26 years and the oldest parents were 52 years.

Table 1. Distribution of respondents by age

\begin{tabular}{cccc}
\hline Variable & Mean \pm SD & Min-Max & $\mathbf{9 5 \%} \mathbf{~ C l}$ \\
\hline Age of child & $10.61 \pm 2,466$ & $7-18$ & $9.91-11.30$ \\
Age of parents & $40.33 \pm 6.405$ & $26-52$ & $38.53-42.13$ \\
\hline
\end{tabular}

Based on Table 2., the characteristics of the research subjects based on the gender 
shows that male children as many as 28 people $(54.9 \%)$, the majority of parents were female as many as 32 people $(62.7 \%)$, the level the education of parents shows that there were 30 people with high school education (58.8\%), the occupation of parents shows that the majority of them were entrepreneurs as many as 22 people (43.1\%).

Table 2. Distribution of respondents based on characteristics

\begin{tabular}{lcc}
\hline \multicolumn{1}{c}{$\begin{array}{c}\text { Characteristics } \\
\text { Indicator }\end{array}$} & Frequency (f) & $\begin{array}{c}\text { Percentage } \\
\text { (\%) }\end{array}$ \\
\hline Child Gender & 28 & 54.9 \\
Male & 23 & 45.1 \\
Female & 51 & 100.0 \\
\hline Total & & \\
\hline Gender of Parents & 19 & 37.3 \\
Male & 32 & 62.7 \\
Female & 51 & 100.0 \\
\hline Total & & \\
\hline Parental Education & 5 & 9.8 \\
Elementary school & 4 & 7.8 \\
Middle School & 30 & 58.8 \\
High school & 6 & 11.8 \\
Academy & 6 & 11.8 \\
Bachelor & 51 & 100.0 \\
\hline Total & & \\
\hline Parents' job & 8 & 15.7 \\
Unemployed & 22 & 43.1 \\
Entrepreneur & 8 & 15.7 \\
PNS / ABRI / Police & 13 & 25.5 \\
Private & 51 & 100.0 \\
\hline Total & & \\
\hline
\end{tabular}

Based on Table 3., most parenting applied by parents in mild mental retardation children was Democratic parenting as many as 40 people (78.4\%).
Table 3. Indicators of parenting

\begin{tabular}{ccc}
\hline Parenting & f & \% \\
\hline Democratic & 40 & 78.4 \\
Authoritarian & 6 & 11.8 \\
Permissive & 5 & 9.8 \\
\hline Total & 51 & 100.0 \\
\hline
\end{tabular}

Based on Table 4., the independence level of Activity Daily Living (ADL) in mild mental retardation children for independence category was 27 people $(52.9 \%)$.

Table 4. Indicators of the level of independence of Activity Daily Living (ADL)

\begin{tabular}{ccc}
\hline ADL Independence Level & $\mathbf{f}$ & $\%$ \\
\hline Independence & 27 & 52.9 \\
Self-sufficient & 18 & 35.3 \\
Less independence & 6 & 11.8 \\
\hline Total & 51 & 100.0 \\
\hline
\end{tabular}

Based on Table 5., parents who adopted democratic parenting as many as 27 people (52.9\%) with the independence level of Activity Daily Living ( $A D L$ ) in mild mental retardation children was in the independent category, and bivariate analysis using the Chi-Square test obtained the value of $p=0.002$ or $p \leq$ 0.05 means there is a relationship between parenting and the independence level of Activity Daily Living (ADL) in children with mild mental retardation of SLB Negeri 1 Tabanan.

\section{Discussion}

\section{Parenting patterns in children with mild mental retardation}

Based on the results of the study, it can be seen that as many as 40 people $(78.4 \%)$ parents

Table 5. The Analysis results of the Relationship between Parenting Parents and the Independence Level of Activity Daily Living (ADL) in Children with Mild Mental Retardation

\begin{tabular}{cccccccccc}
\hline & \multicolumn{8}{c}{ Level of Independence Daily Living Activity (ADL) } \\
\hline Parents' & \multicolumn{2}{c}{ Independent } & \multicolumn{2}{c}{ Enough } & \multicolumn{1}{c}{ Less } & \multicolumn{1}{c}{ Total } & p-value \\
Parenting & $\%$ & $\mathrm{f}$ & $\%$ & $\mathrm{f}$ & $\%$ & $\mathrm{f}$ & $\%$ & & \\
Democratic & 27 & $52.9 \%$ & 9 & $17.6 \%$ & 4 & $7.8 \%$ & 40 & $78.4 \%$ & \\
Authoritarian & 0 & $0 \%$ & 5 & $9.8 \%$ & 1 & $2.0 \%$ & 6 & $11.8 \%$ & \\
Permissive & 0 & $0 \%$ & 4 & $7.8 \%$ & 1 & $2.0 \%$ & 5 & $9.8 \%$ & \\
\hline Total & 27 & $52.9 \%$ & 18 & $35.3 \%$ & 6 & $11.8 \%$ & 51 & $100.0 \%$ & 0.002 \\
\hline
\end{tabular}


apply democratic parenting. According to Hurlock (2013) democratic parenting shows that parents are allowing children to not always depend on parents, given freedom, respect for what has been achieved and at the same time responding to their children for what they do, always discussing with children, always listening to the complaints and opinions of their children, parents always involve children in making decisions about themselves in organizing the schedule of activities and appreciate every success that has been obtained by children (12). The results obtained were supported by the results of the research by Maulinda (2013) that the majority of parents parenting were democratic as many as 24 people (55.8\%) (13). Sari's research (2014) were $61.9 \%$ applied democratic parenting, where the majority (54.0\%) of respondents had tertiary education (9).

Job factors can also affect the pattern of democratic parenting adopted by parents. The results showed in terms of occupation, parents who worked in civil servants/military/police as many as 8 people $(15.7 \%)$ applied democratic parenting, parents who worked in self-employed implemented democratic parenting as many as 15 people (29.4\%), parents who work in the private sector apply democratic parenting as many as 13 people $(25.5 \%)$ and parents who do not work apply democratic parenting as much as 4 people $(7.8 \%)$. The age factor of parents can influence parents to apply democratic parenting when caring for their children. The results showed the characteristics of parents of mild mental retardation children based on age showed $26-52$ years old with an average of 40.33 years. According to Supartini (2004) in Dewi (2017) said that parents with a certain age range are in running the role of care. The age that is too young or too old, may not be able to carry out this role optimally because it requires physical and psychosocial strength (14). The researchers believe that highly educated parents always discuss with their children, it is proven when the children are resting, parents invite their children to discuss what their children want to do, parents diligently accompany their children, parents give responsibilities and educate their children in terms of independence.

\section{Level of Independence of Daily Living Activity (ADL) in Children with Mild Mental Retardation}

The results of the study showed the independence level of Activity Daily Living in children with mild mental retardation, it was 27 people $(52.9 \%)$ in the independent category, this is following Soetjiningsih (2013) who stated that mild mental retardation children have an IQ of 52-69 which is classified in the category of retardation that can be educated and trained (trainable) and they get to benefit from the exercise with adequate supervision so that children in this category can maintain self-care to be carried out independently (15).

According to Effendi (2012), the growth and development of children following the classification of mental retardation affect the ability of children to perform mental selfretardation. The ability of self-care children with mild mental retardation is categorized as independent so that parental guidance is needed to be able to maintain the independence that children can do so that it can still be done independently (2012). The results of this study were supported by Arfandi (2013), it was found that self-care abilities of mentally retarded children in SLB Negeri Ungaran (58.7\%) were in the independent category (6). Kendari (2016) stated that a number $(32.1 \%)$ of children with mild mental retardation, their level of care in the sufficient category (17).

Besides, the child's age factor can also affect a child's independence. The results showed that the average age of the child was 10.61 years. According to Sandra (2010), the 
more age will increase the child's ability to master certain skills. Mental retardation children with older age will master more self-care skills than mental retardation children who are younger. This is due to the mental development of mental retardation children who are not the same as normal children in general, so that mastery of self-care skills will also be slower than normal children of the same age (18).

Researchers believe the ability of mild mental retardation children in self-caring can be categorized as independence, which requires guidance from parents to maintain their independence. Independence of children with mental retardation is evidenced by the appearance of children eating alone with clean hands because they have been washed before, children eat using a spoon well, when the children are taken by their parents to the school, the children can go to the classroom by themselves, and when the clothes come off, the children repair their clothes well.

The relationship between parenting and the level of independence of Activity Daily Living (ADL) in mild mental retardation children

Based on the Chi-Square test results obtained $p$-value of $0.002<$ from the significance level determined that 0.05 results indicate that there is a relationship between parenting and the independence level of Activity Daily Living (ADL) in children with mild mental retardation in SLB Negeri 1 Tabanan in 2019. According to Wong (2009) parenting style is seen as a determinant factor that influences the development of Activity Daily Living independence such as personal hygiene, elimination, eating, drinking, and dressing (7). The results of this study were supported by the results of research conducted by Rumaseb (2018). The results obtained $p$-value $<\alpha(0,000<0.05)$. It can be concluded that there was a parenting pattern towards the level of independence of mental retardation children aged 10-14 years in self-care (19). Kendari research (2016) found $p$-value $0,000(p>0.05)$ it can be concluded that there is a relationship between parenting style and the level of self-care independence in mild mental retardation children in SDLB C Negeri Denpasar (17). The results showed that 27 parents $(52.9 \%)$ adopted democratic parenting and the independence level of Activity Daily Living in children with mild mental retardation was in the independent category. According to Petranto (2012) parents have adopted good parenting, characterized by an open attitude between parents and children, allowing children to be independent and developing internal control, their existence recognized and involved in decision making in the family (20).

The results of the study that parents who apply authoritarian parenting as many as 5 people $(9.8 \%)$ and the independence level of daily living activity in children with mild mental retardation were in the category of quite independent. Parents who apply this parenting, according to Petranto (2012) can be seen from the attitude of parents who do not provide opportunities for children to express their opinions or desires, control of children's behavior is very strict, parents punish children if they are not obedient, parents demand children to meet the rules for the standards applied by parents, parents limit the freedom of children. This parenting encourages children to be timid, reserved, introverted, weak, anxious and withdrawn (20)

The results of the study also showed that parents who apply permissive parenting as many as 4 people $(7.8 \%)$ and the independence level of daily living activity in children with mild mental retardation were in the category of quite independent. Parents who apply this parenting, according to Petranto (2012) can be seen from the attitude of parents who give freedom to their children to do whatever they like, parents do 
not reprimand their children's behavior, parents give full freedom to their children, parents are loose. This parenting encourages children to become children who are less independent, spoiled, lacking confidence, and have difficulty in adjusting themselves (20).

\section{CONCLUSIONS AND RECOMMENDATION}

The majority of parenting applied to mild mental retardation children in SLB Negeri 1 Tabanan was democratic parenting as many as 40 people $(78.4 \%)$ and the independence level of Activity Daily Living (ADL) which was in the independent category were 27 people $(43.1 \%$ ). The results of the $p$-value analysis of 0.002 are less than a significant level of 0.05 , which means that there is a relationship between parenting and the independence level of Activity Daily Living (ADL) in mild mental retardation children in SLB Negeri 1 Tabanan in 2019. It is expected that parents apply appropriate parenting to their children and gives encouragement to their children to be able to explore their potential and abilities by providing many positive activities so that children can learn independently, especially in daily living activities. Teachers in the research area are expected to be able to provide examples and independent behavior in self-care daily living activities for students to be applied by students, both at home and at school. It is hoped that Health Officers (Puskesmas) can increase their role in conducting assessments and planning training programs and health education related to skills in daily mental activities of children with mild mental retardation. Future studies are expected to be used as reference materials and references for further research.

\section{REFERENCES}

1. Toifur. 2012. Model Pembelajaran Pendidikan Agama Islam bagi Anak Tuna Grahita. Jurnal al-Munqidz. Vol 1 Edisi 2.p123-139
2. Ramawati, Allenidekania, dan Besral. 2012. Kemampuan Perawatan Diri Anak Tunagrahita Berdasarkan Faktor Eksternal dan Internal Anak. Jurnal Keperawatan Indonesia, Volume 15, No. 2. p89-96

3. World Health Organization. 2017. Mental Retardation. (Online). Available from: http:// mediaindonesia.com/read/detail/201266pelatihan-start-upkewirausahaan bagiremaja-disabilitas (31 December 2018)

4. Pratiwi. 2017. Kemampuan Kognitif Anak Retardasi Mental Berdasarkan Status Gizi. Public Health Perspective Journal. p19-25. p-ISSN 2528-5998

5. Dinas Provinsi Bali. 2017. Rekam Medis Dinas Kesehatan Provinsi Bali 2017

6. Arfandi, Z. 2013. Kemandirian Perawatan Diri pada Anak Retardasi Mental di SLB Negeri Ungaran. Available from: https://anzdoc.com/ hubungan-antara-dukungan-sosial-keluargadengan-kemampuan-pe.html (06 Januari 2019)

7. Wong, D. L. 2009. Buku Ajar Keperawatan Pediatrik (Agus Sutarna, Neti Juniarti, \& $\mathrm{H}$. Y. Kuncara, penerjemah). Volume 1 Edisi 6. Jakarta:EGC Penerbit Buku Kedokteran

8. Tarmudji. 2012. Hubungan Pola Asuh Orang Tua dengan Ageresivikasi Remaja. Jurnal Kesejahteraan Keluarga dan Pendidikan. p7-11

9. Sari D. 2014. Hubungan Pola Asuh Orang Tua Dengan Perkembangan Sosial Anak Retardasi Mental Di SLB C Negeri Denpasar. Skripsi. STIKes Wira Medika Bali

10. Apriliyanti, D. 2016. Hubungan Pola Asuh Orang Tua dengan Tingkat Kemandirian Personal Hygiene pada Anak tunagrahita di SLBN 1 Palangkaraya. Jurnal Dinamika Kesehatan. p43-50.

11. SLBN 1 Tabanan. 2017. Rekapitulasi Data Sekolah Luar Biasa Negeri 1 Tabanan 2017 12. Hurlock, E.B. 2013. Psikologi Perkembangan anak. Jakarta: Erlangga 
13. Maulinda. (2013). Hubungan Pola Asuh Orang Tua dengan Tingkat Kemandirian Pemenuhan Kebutuhan ADS (Aktivitas Dasar Sehari-hari) pada Anak Tunagrahita Sedang di SLB Widya Mulia Pundong Bantul. (Online). Available from: http://repository. unjaya.ac.id/932/ (08 April 2019)

14. Dewi, V K. 2017. Hubungan Pola Asuh Orang Tua Dengan Tingkat Kemandirian Anak Retardasi Mental Ringan Di Sdlb Yplb Banjarmasin. Available from: https:// docplayer.info/72236957.html (16 April 2019)

15. Soetjiningsih, IG.N. 2013. Tumbuh kembang anak. Jakarta:ECG

16. Effendi, M. 2012. Pengantar Psikopedagodik Anak Berkelainan. Jakarta : PT. Bumi Aksara

17. Kendari,S. 2016. Hubungan Pola Asuh Orang Tua dengan Tingkat Kemandirian Perawatan
Diri pada Anak Retardasi Mental. Skripsi. STIKes Wira Medika Bali

18. Sandra, M. 2010. Anak Cacat Bukan Kiamat: Metode Pembelajaran dan Terapi untuk Anak Berkebutuhan Khusus. Yogyakarta: Katahati 19. Rumaseb. 2018. Hubungan Pola Asuh Orang Tua Dengan Tingkat Kemandirian Anak Retardasi Mental Usia 10-14 Tahun Dalam Melakukan Perawatan Diri di SLB Negeri Bagian B Jayapura (Online). Available from: http://www._digilib.unimus.ac.id/download. php?id=9686 (12 April 2019)

20. Petranto, I. 2012. Rasa Percaya Diri Adlah Pantulan Pola Asuh Orang Tuanya. (Online). Available from: http://www.dwpptrijenewa. issues.com (08 Januari 2019) 